\title{
Continuous Photoautotrophic Cultures of the Eukaryotic Alga Chlorella vulgaris Can Exhibit Stable Oscillatory Dynamics
}

\author{
Minoo Javanmardian and Bernhard O. Palsson* \\ Cellular Biotechnology Laboratory, Department of Chemical Engineering, \\ The University of Michigan, Ann Arbor, Michigan 48109-2136
}

Received June 11, 1991/Accepted August 21, 1991

\begin{abstract}
Sustained oscillations in cell concentration, average per cell DNA content, and average cell size were found in continuous photoautotrophic cultures of Chlorella vulgaris at low dilution rates $(0.1 /$ day). The period of oscillation was approximately 10 days. DNA histograms determined by flow cytometry exhibited reproducible pattern through consecutive oscillations. At the maximum cell concentration during an oscillation, the DNA histograms showed that the majority of the cells were not replicating their chromosomes, and most of the culture was comprised of single cells in G0/G1 phase. The cells then initiated DNA replication; however, because of the long generation time, the cell concentration decreased to a minimum, and at the same time the average per cell DNA content reached its maximum value. At this point the cells began to divide, and the cell concentration increased until it reached its maximum value at the beginning of the next oscillation. Calculations based on the supplied nutrients and comparison to biomass generation showed that the oscillatory behavior in continuous photoautotrophic cultures of $C$. vulgaris was not due to nutrient limitation, but most likely was due to the secretion of compounds that alter cell cycle kinetics. The oscillatory behavior disappeared when the dilution rate was increased to $0.3 /$ day and the culture reached a stable steady state.

Key words: Photoautotrophic growth - Chlorella vulgaris oscillations • autoinhibitor - flow cytometry
\end{abstract}

\section{INTRODUCTION}

Different strains of algae are potential sources of important biotechnologic products such as pharmaceutical and genetically engineered products. ${ }^{2,9,10,19,23}$ However, in spite of their biotechnologic potential, the development of photoautotrophic cell cultures has lagged behind the development and use of heterotrophic cultures. ${ }^{4}$ The major challenge in utilizing such cultures to produce valuable products is to be able to grow photoautotrophic cells at high viable cell concentrations. To accomplish this task, two major issues need to be addressed: first, the design of suitable photobioreactor systems, and second, the detailed study of cell cycle kinetics of photoautotrophic cultures at high cell densities. A variety of photobioreactors has been designed for high-density algal cultures, ${ }^{12,15,16}$ but only recently have cell concentrations of $3 \%(\mathrm{wt} / \mathrm{vol})$ been reached in photoautotrophic cultures. ${ }^{12}$

\footnotetext{
* To whom all correspondence should be addressed.
}

Biotechnology and Bioengineering, Vol. 39, Pp. 487-497 (1992)

(C) 1992 John Wiley \& Sons, Inc.
Cell cycle kinetics of photoautotrophic algae at high cell concentrations have thus not been studied yet. Our recent study, with the eukaryotic alga Chlorella vulgaris in a customized photobioreactor system that has a high volumetric light intensity, ${ }^{12}$ showed that the cell cycle behavior at low and high cell density differs significantly. This study concluded that the change in cell cycle behavior was due to secreted compounds. This observation was in agreement with the studies that Pratt and coworkers ${ }^{17-22}$ performed in the early to mid-1940s that concluded that $C$. vulgaris produces autoinhibitory factors at high cell densities.

A second study was subsequently conducted to understand further the effect of conditioned medium derived from high-density algal cultures on the cell cycle kinetics at low density. ${ }^{11}$ This study led to the conclusion that in the presence of spent medium from high density photoautotrophic cultures, the kinetics of cell growth differ from those described by the classical $C$. vulgaris cell cycle, which basically consists of multiple synchronous binary fissions of the mother cell's nucleus to produce $2^{n}$ daughter cells per division burst. ${ }^{1,26}$ Further, the duration of the G0/G1 phase in the $C$. vulgaris cell cycle is believed to comprise a significant portion of the complete cell cycle period. ${ }^{7}$ The results from batch cultures at low cell densities, supplemented with conditioned medium from high-density photoautotrophic culture, showed that the presence of conditioned medium affects the total duration of the cell cycle. Especially, the conditioned medium results in temporary or in some cases permanent blockage of progression through the cell cycle after the first round of chromosomal replication. ${ }^{11}$

The current study was conducted to examine the influence of secreted cell cycle modifying compounds on continuous photoautotrophic cultures of $C$. vulgaris, by investigating growth of $C$. vulgaris at low and high dilution rates. If secreted growth altering compounds affect the total timing of the cell cycle, specifically the duration of the cell cycle after the first round of chromosomal replication, ${ }^{11}$ then one would expect to observe oscillatory behavior in continuous cultures at low dilution rates. Oscillations are expected because at low dilution rates, the concentrations of any growth-altering compounds may be significant, and if they affect the total 
timing of the cell cycle by blockage following the first round of chromosomal replication, then there will be periods during which cells are arrested in the cell cycle, and the mother cells will not divide to release autospores. Arresting the cells in the cycle will cause the cell concentration to decrease; however, once the cell cycle modifying compound(s) is diluted, the mother cells will begin to divide, and the cell concentration will increase. This pattern should then repeat itself regularly if this prediction proves to be correct. Conversely, operation at high dilution rates would prevent buildup of growthaltering factors, and such oscillations are not expected.

\section{MATERIALS AND METHODS}

C. vulgaris, Emerson strain, obtained from Carolina Biological Supplies, was cultivated in N-8 medium in a 3-L New Brunswick Bioflo II (New Brunswick Scientific, $\mathrm{NJ}$ ), with a $2.5-\mathrm{L}$ working volume. The medium consisted of six macronutrients (mg/L): $\mathrm{Na}_{2} \mathrm{HPO}_{4} \cdot 2 \mathrm{H}_{2} \mathrm{O}$, $260 ; \mathrm{KH}_{2} \mathrm{PO}_{4}, 740 ; \mathrm{CaCl}_{2}, 10 ; \mathrm{Fe}$ EDTA, 10; $\mathrm{MgSO}_{4}$. $7 \mathrm{H}_{2} \mathrm{O}, 50 ; \mathrm{KNO}_{3}, 1000$. The micronutrients were supplied by adding $1 \mathrm{~mL}$ of trace element stock solution to $1 \mathrm{~L}$ of macronutrient solution. The composition of micronutrient stock was $(\mathrm{g} / \mathrm{L}): \mathrm{Al}_{2}\left(\mathrm{SO}_{4}\right)_{3} \cdot 18 \mathrm{H}_{2} \mathrm{O}, 3.58$; $\mathrm{MnCl}_{2} \cdot 4 \mathrm{H}_{2} \mathrm{O}, 12.98 ; \mathrm{CuSO}_{4} \cdot 5 \mathrm{H}_{2} \mathrm{O}, 1.83$; and $\mathrm{ZnSO}_{4}$. $7 \mathrm{H}_{2} \mathrm{O}, 3.2$. The salts were dissolved in deionized water. The Bioflo II unit has a top-driven stirrer, a watercooled condenser on the air outlet line, and control systems for foam, temperature, $\mathrm{pH}$, and dissolved oxygen (DO). The culture was grown at a constant temperature of $25^{\circ} \mathrm{C}$, and it was illuminated by two circular GE cool white 40-W fluorescent lamps. This method of illumination provided a light intensity in the order of $10-15 \mathrm{~mW} /$ $\mathrm{cm}^{2}$ at the surface of the reactor. Air supplemented with 5\% carbon dioxide was sparged through the reactor with a flow rate of $100 \mathrm{~mL} / \mathrm{min}$. During the continuous mode, the fresh medium was pumped in the reactor via a built-in peristaltic pump and the outlet from the reactor was via overflow side ports so that the total volume of the culture was constant.

The cell concentration was measured by Coulter Counter Model ZM (Coulter Electronics, Inc., Hialeah, FL). This unit also includes a Coulter Channelyzer, which can measure particle size distributions. The analysis of size distribution is done via Coulter AccuComp System for the Channelyzer C256 Instrument. The program provides volume and population statistical analysis, as well as a variety of kinds of data display, such as differential population, differential volume, etc. A hemocytometer was also used to verify the results from Coulter Counter.

The per cell DNA content of the cells was quantified using flow cytometry. Samples containing a total number of $10^{6}$ cells were centrifuged $(280 \times \mathrm{g}, 10 \mathrm{~min})$, suspended in a small volume $(<0.2 \mathrm{~mL})$ of supernatant, and added to $1 \mathrm{~mL}$ of ice-cold methanol. The samples were stored for 10 days at $4^{\circ} \mathrm{C}$. For DNA staining, the samples were centrifuged $(280 \times \mathrm{g}, 7 \mathrm{~min})$, and resuspended in methanol for $45 \mathrm{~min}$ to extract all the remaining chlorophyll. After this stage the samples were centrifuged $(280 \times \mathrm{g}, 7 \mathrm{~min})$, washed with phosphate buffer solution (PBS) once, then resuspended in $1 \mathrm{mg} / \mathrm{mL}$ of RNase in PBS for $45 \mathrm{~min}$ at $37^{\circ} \mathrm{C}$, after which the DNA was stained with propidium iodide (PI) in a concentration range between 30 and $40 \mu \mathrm{g} / \mathrm{mL}$. Samples were stained and analyzed in groups of 30 samples. An internal standard such as chicken red blood cell was not used for DNA analysis of Chlorella cells because of the overlap of the standard and sample DNA histograms. Instead, an external standard was used frequently as a staining control. ${ }^{11}$

Stained samples were analyzed on a Coulter EPICS 751 flow cytometer (Coulter Corporation, Hialeah, FL), equipped with a 5-W argon laser. The laser was tuned to $488 \mathrm{~nm}$, and the power output was set to $200 \mathrm{~mW}$. The DNA histograms comprised of 256 channels on a linear scale were acquired to a total count of 30,000. The linear voltage was adjusted to allow the inclusion of all DNA peaks in a single linear histogram. The DNA histograms were bitmapped off of two-parameter histograms to eliminate electronic noise and signals generated from cellular debris. The light energy emitted from the PIDNA complex was directed to a photomultiplier tube by a $550-\mathrm{nm}$ dichroic beam splitter followed by a $630-\mathrm{nm}$ long-pass filter.

To analyze the flow cytometric DNA histograms, Cytologic Software (Version 2.0, Coulter Cytometry) can be used under certain circumstances. One of the main conditions for using this software is to have highly resolved peaks in DNA histograms with defined valleys (e.g., the typically bimodal DNA histograms from exponentially growing mammalian cells). However, in the case of oscillatory dynamics in continuous photoautotrophic cultures of $C$. vulgaris, the DNA histograms were not resolved, and it was not possible to use Cytologic Software to analyze the histograms.

In order to estimate the percentage of cells present in G0/G1 phase, during the oscillation period, a Gaussian curve was fit to the first peak of the DNA histograms using the following formula:

$$
y=\frac{\exp \frac{-(x-\mu)^{2}}{2 \sigma^{2}}}{\sigma \sqrt{2 \pi}}
$$

where:

- $y$ is the number of cells in each channel.

- $x$ is the channel number.

- $\mu$ is the channel number corresponding to the maximum number of cells with one chromosomal equivalent.

- $\sigma$ is the standard deviation.

In our case the best results were obtained with a standard deviation of 4.8 and an average $\mu=34$. The Gaussian curve with these specifications was fitted to 
the left half of the first peak (channels 1-34). The percentage of cells in $\mathrm{G} 0 / \mathrm{G} 1$ phase was then calculated by using a least square method (see Fig. 7 and associated discussion below).

\section{RESULTS}

C. vulgaris was grown in the Bioflo II bioreactor to a concentration of $1.5 \times 10^{8}$ cells $/ \mathrm{mL}$ in a batch mode over a period of 12 days. The reactor was then put into a continuous mode with a low dilution rate of $0.1 /$ day. For the first 8 days after the onset of continuous operation, there was virtually no growth, and the culture was diluted [Fig. 1(A)]. By day 24 the cells resumed growth; however, a steady state cell concentration was never achieved, and the cell number oscillated continuously between $1.5-3.0 \times 10^{7}$ cells $/ \mathrm{mL}$ in regular and repro-

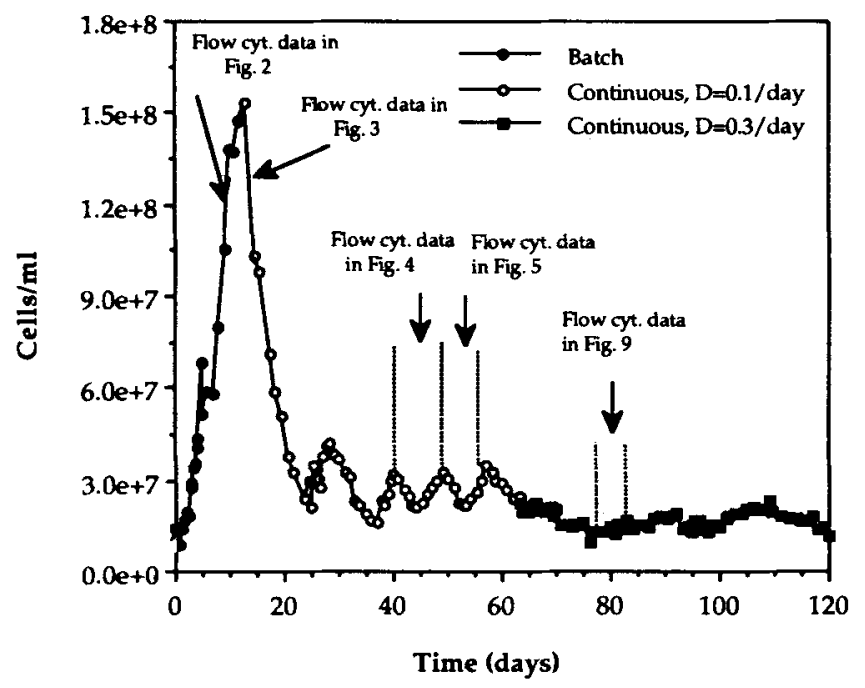

(A)

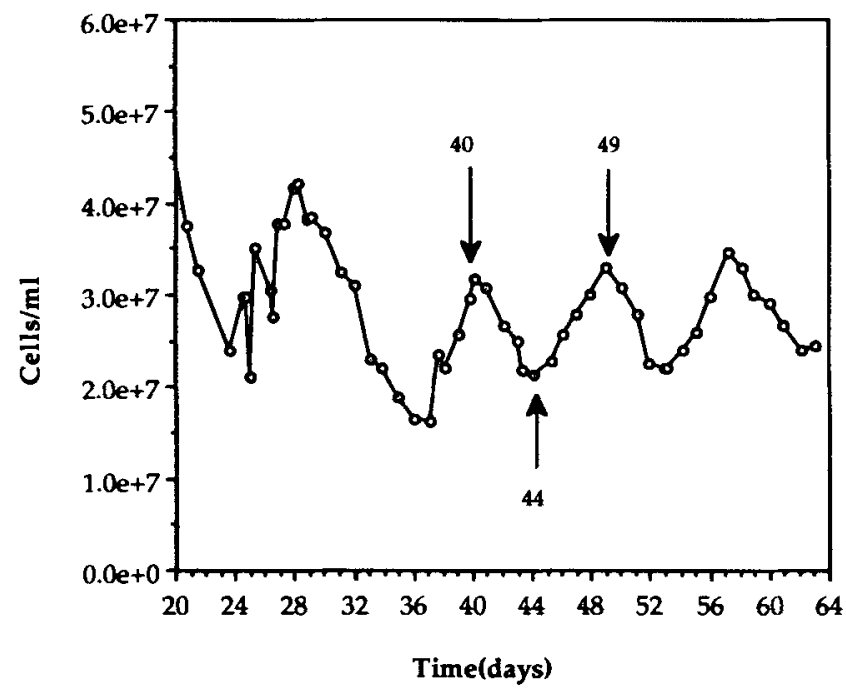

(B)

Figure 1. (A) Cell-concentrations of Chlorella vulgaris in batch and continuous culture at different dilution rates. (B) A close-up of the cell concentration during the oscillation periods. ducible fashion over a period of 30 days [Fig. 1(B), from day 36 to day 64$]$.

On day 64 the dilution rate was increased to $0.3 /$ day. The oscillatory behavior disappeared at this dilution rate, and a steady state concentration was achieved at approximately $1.5 \times 10^{7}$ cells $/ \mathrm{mL}$, which remained constant over a period of 2 months until the experiment was terminated [Fig. 1(A)]. Note that by a 3-fold increase in dilution rate, the steady state concentration changed only by a factor of about 1.5 (assuming the average cell density during oscillatory period is about $2.25 \times 10^{7}$ cells $/ \mathrm{mL}$ ). Accordingly, the number of new cells generated per unit time at dilution rate of $0.1 /$ day $\left(2.25 \times 10^{6}\right.$ cells $/ \mathrm{mL} /$ day $)$ was about 2.0 -fold lower than the number of cells generated at 0.3 /day dilution rate $\left(4.5 \times 10^{6}\right.$ cells $/ \mathrm{mL} /$ day $)$.

The DNA distributions were obtained via flow cytometer during the batch mode and continuous operation at low and high dilution rates. At the early stages of the batch culture, the DNA distribution had a broad pattern characteristic of an exponentially growing culture (Fig. 2, days 0, 1, and 4). However, as the cell concentration reached a maximum and the growth rate ceased, the DNA distribution became narrow and formed a sharp peak corresponding to one genome equivalent (Fig. 2, days 11 and 13).

For the first few days following the onset of continuous operation, the DNA histograms did not change (Fig. 3, days 14 and 15). By day 19, after 7 days of continuous culture, the DNA histograms began to broaden showing commitment to DNA replication (Fig. 3, days 19 and 21). A few days later, a significant number of cells reached high DNA contents, cell division started, and the cell concentration began to increase (Fig. 3, days 22 and 24). Note that only a fraction of the cells began to cycle as evidenced by presence of the sharp peak that corresponds to one genome equivalent.

The flow cytometric DNA histograms were obtained for the three oscillations during days 36-64. The results obtained from each of the three oscillations were essentially identical. The time sequence of DNA histograms from the second and third oscillation is shown in Figures 4 and 5. The DNA distributions from the second period of oscillation may be compared to the size distributions of the culture during the same period of time (Fig. 6). Such comparison shows that the DNA content and size distribution had a very similar temporal pattern. On day 40 , when the cell concentration is at a maximum, both the DNA and size distribution patterns were unimodal distributions with very few cells at higher size or higher DNA content showing that the culture was comprised of single cells that were not undergoing DNA replication. By day 42 a significant portion of the cells had initiated DNA replication; however, very few cells were dividing and releasing autospores. Thus, the cell concentration was decreasing during this time period. Following day 44 , the cells began to divide, 


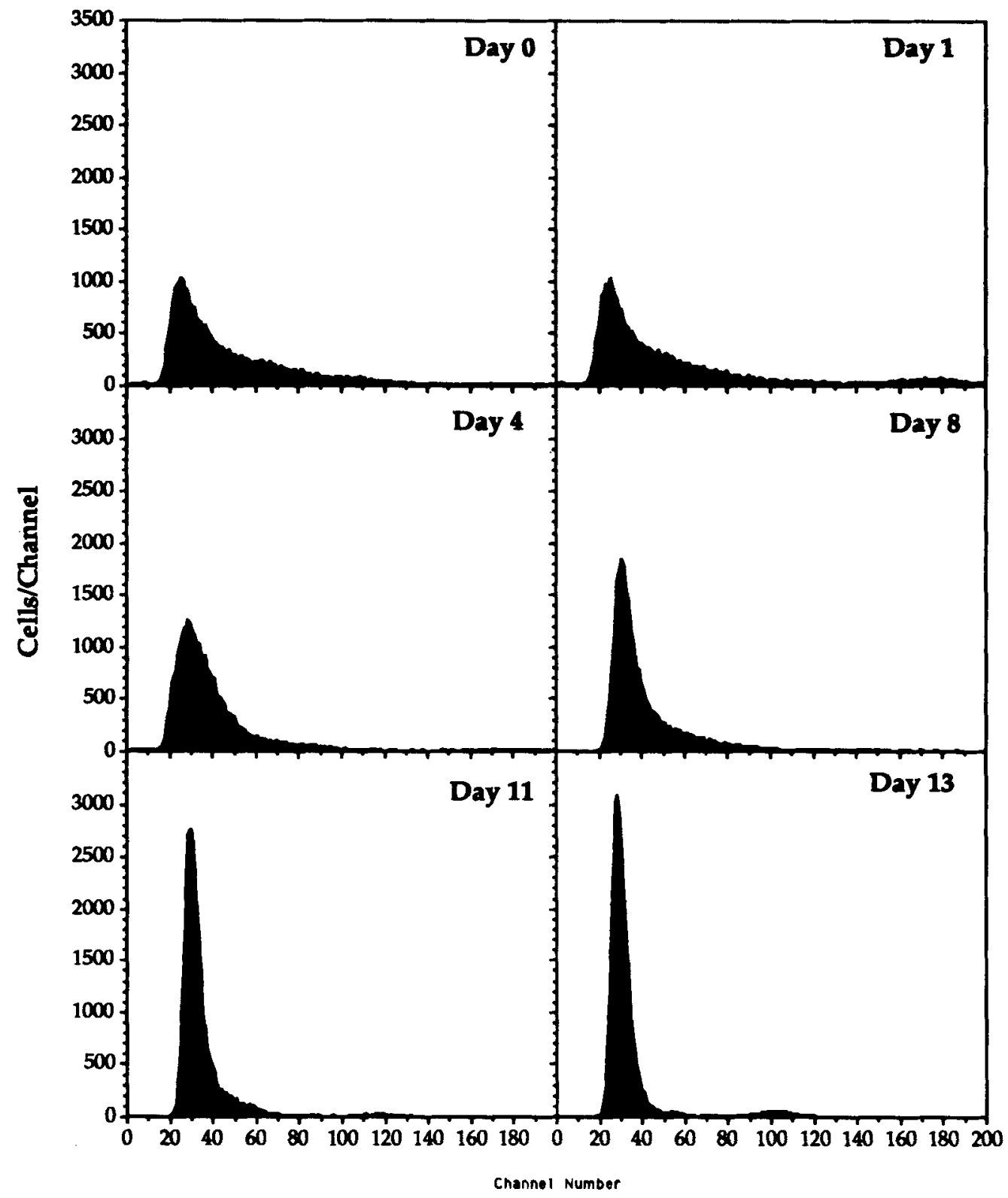

Figure 2. The time sequence of DNA histograms during the batch mode before the culture was put into continuous mode; see Figure 1 and text for details.

releasing autospores, causing the DNA histograms to show a pronounced peak corresponding to one chromosomal equivalent, and lower average size (from approximately $57 \mathrm{fl}$ at day 44 to $38 \mathrm{fl}$ at day 49 ). By day 49 almost all autospores had been released, and this cycle repeated itself during the next period of oscillation.

An exponentially growing culture has an asymmetric unimodal and broad DNA distribution with a constant percentage of cells in each phase of the cell cycle, similar to the data shown in Figure 2, days 0, 1, and 4. Therefore, the percentage of the G0/G1 phase in an exponentially growing culture is expected to be constant, and it usually accounts for about $70 \%$ of the cells in a C. vulgaris culture with 20 -h doubling time.

To analyze the cell cycle kinetics in more detail, the percentage of G0/G1 phase was calculated during the second oscillation. The data were calculated by fitting a Gaussian distribution to the first peak of the DNA histograms with a mean of 34 and a standard deviation of 4.8. Figure 7 illustrates graphically how the distribution of overall population compares to the Gaussian curve that is estimated to represent the G0/G1 part of the distribution. The percentage of cells estimated to have been in the G0/G1 phase changes significantly through one oscillation, and their percentage changes from $65 \%$ to $20 \%$ between days 40 and 43 , respectively [Fig. 8(A)].

The average per cell DNA content was readily calculated from the DNA histograms. The results of such calculation show that the average DNA content oscillates in a reproducible fashion [Fig. 8(B)]. Comparison between the average DNA content and the cell concentration [Fig. 1(B)] during the entire oscillatory period shows 


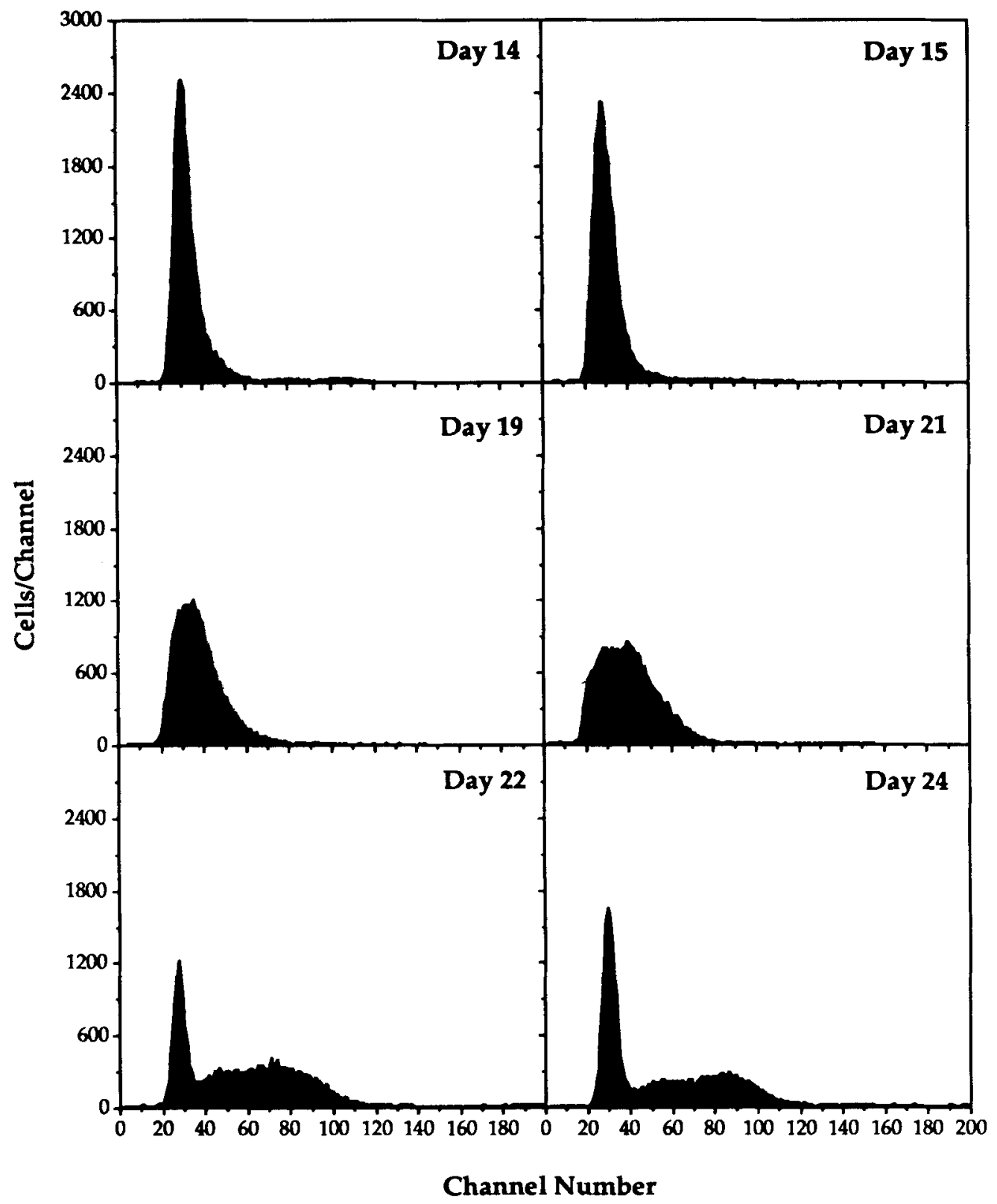

Figure 3. The time sequence of DNA histograms during the first 10 days of continuous cultivation, during which virtually no cell growth was observed; see Figure 1 and text for details.

that the DNA content oscillates completely out of phase with the cell concentration. The average DNA content is at a maximum when the cell concentration is at a minimum and vice versa for each oscillation.

Increasing the dilution rate to 0.3 /day eliminated the oscillatory behavior. The cell concentration stabilized at a value of $1.5 \times 10^{7}$ cells $/ \mathrm{mL}$ [Fig. $1(\mathrm{~A})$ ]. The DNA histograms obtained at high dilution rate between days 78 and 82 showed a broad unimodal distribution that is characteristic of normal exponential growth (Fig. 9). The cell size distribution had also a similar pattern (data not shown). Thus, the oscillations disappeared at higher dilution rates, indicating that the culture had resumed its balanced exponential growth.

\section{DISCUSSION AND CONCLUSIONS}

Stable oscillatory behavior was observed in continuous photoautotrophic cultures of the eukaryotic alga $C$. vulgaris at low dilution rates. Sustained oscillatory behavior in continuous cultures of lower eukaryotic microorganisms such as Saccharomyces cerevisiae have been reported. ${ }^{5,6}$ The sustained oscillations in yeast cultures have been attributed to the buildup and toxic effects of ethanol, as well as nutrient limitations, especially limitations in carbon source such as glucose. . $^{3,5,6,25,27}$

Unlike oscillations in continuous yeast cultures, sustained oscillatory dynamics in continuous photoautotrophic cultures of $C$. vulgaris are not due to nutrient 


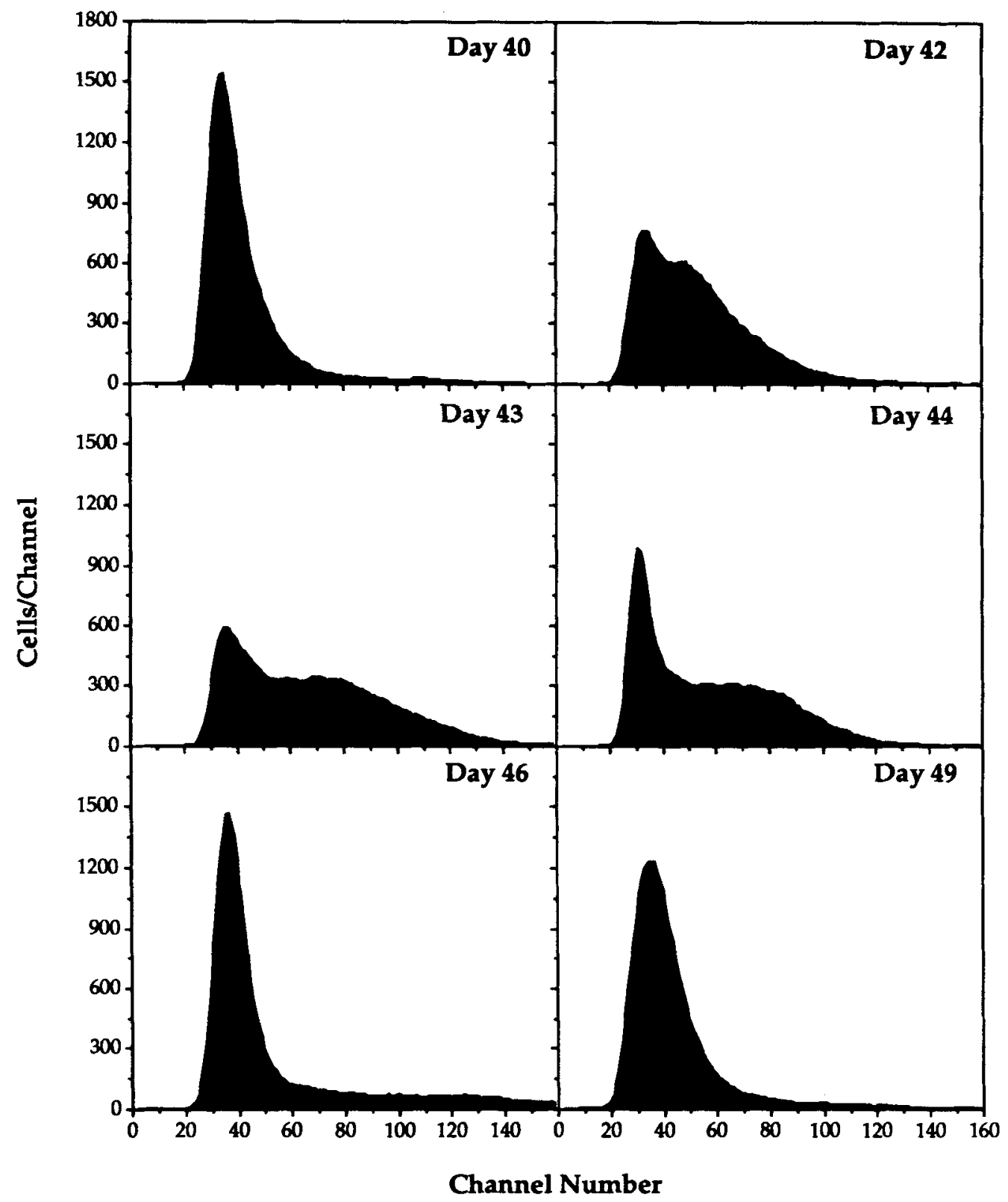

Figure 4. The time sequence of DNA histograms during the second period of oscillation (days 40-50); see Figure 1 and text for details.

limitations. Dry Chlorella cells have a composition of $52.8 \% \mathrm{C}, 7.9 \% \mathrm{H}, 30.5 \% \mathrm{O}$, and $8.8 \% \mathrm{~N} .{ }^{16}$ Because the culture is completely photoautotrophic and the carbon dioxide is the only carbon source, it is possible to calculate the maximum biomass productivity of the culture from the supplied carbon dioxide. Similar calculations can be carried out for the nitrogen source. The details of these calculations are outlined in the Appendix. Such calculations show that the carbon dioxide supplied to the culture is enough to support a biomass productivity of approximately $3.0 \times 10^{9}$ cells $/ \mathrm{mL} /$ day, and the supplied nitrogen allows for biomass productivities as high as $2 \times 10^{8}$ cells $/ \mathrm{mL} /$ day. These calculations were done under the assumption that the average cell volume was $40 \mathrm{fl}$ per cell (from our cell size measurements through Coulter Channelyzer), and that the ratio of dry to fresh weight for the cells was $0.25 .^{8}$ Comparison between these calculated productivities with the measured productivity of the culture at low dilution rate $(2.25 \times$ $10^{6}$ cells $/ \mathrm{mL} /$ day) showed at least two orders of magnitude difference. Thus, the culture was not limited by its carbon or nitrogen source.

The data reported herein and the calculations based on them are consistent with our previous studies that show that $C$. vulgaris secrete compound(s) at high cell concentrations that affect their cell cycle. Specifically, the presence of conditioned medium appears to inhibit the second round of initiation of DNA replication. Only one of the nuclei resulting from the first round of DNA replication initiates and completes DNA synthesis, while the other does not. The result is that the majority, sometimes all, of the cells in the batch cultures with 


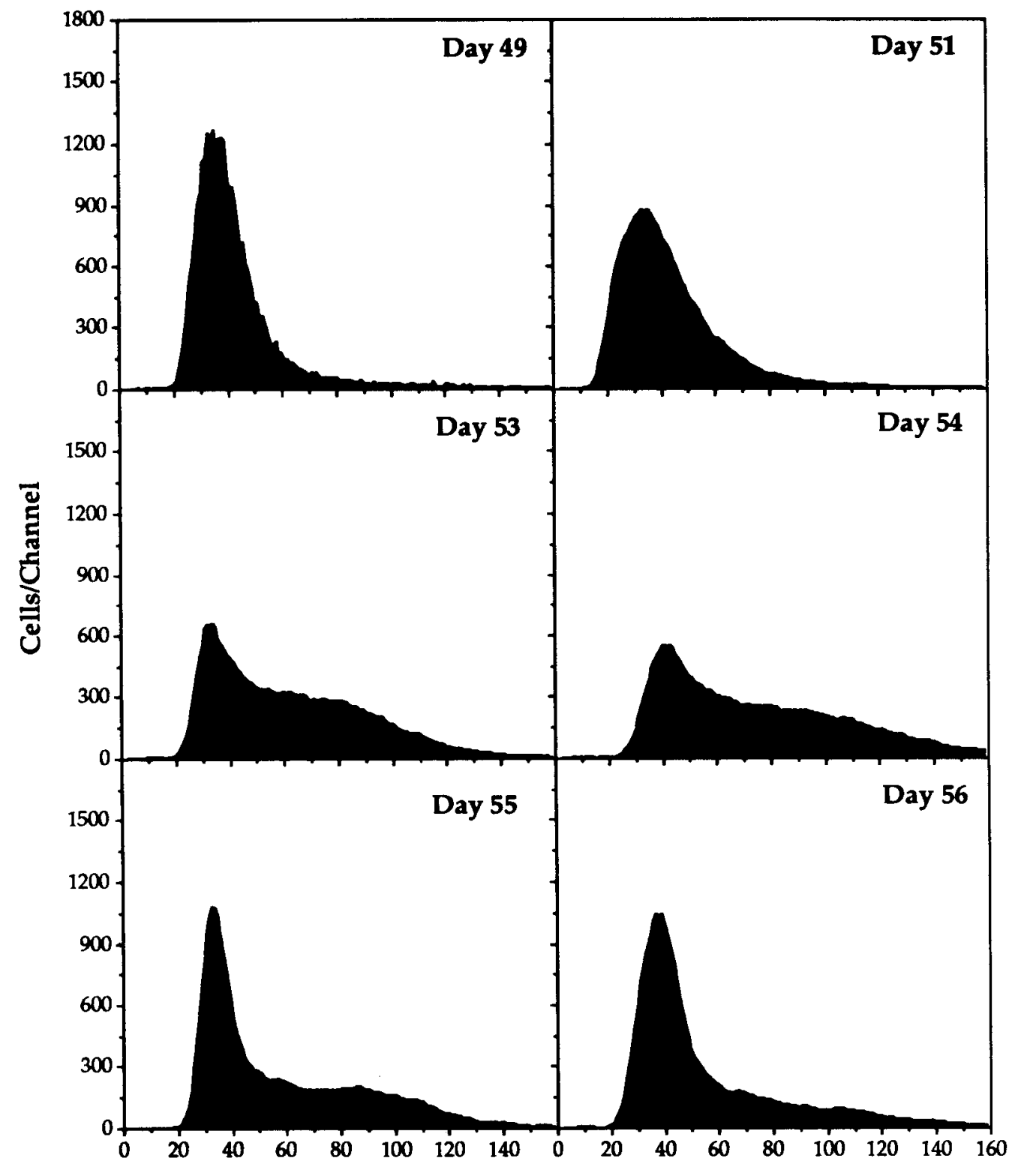

Channel Number

Figure 5. The time sequence of DNA histograms during the third period of oscillation (days 50-60); see Figure 1 and text for details.

conditioned medium end up as mother cells containing three autospores.

The oscillations reported in this study can be interpreted in view of the inhibitory mechanism just outlined. For purposes of this discussion, we take the beginning of a cycle to be at the minimum cell concentration, e.g., close to day 44 . At this point we estimate that about $65 \%$ of the cells are cycling and the average DNA content is just above 2 (see Fig. 8). Thus, the average DNA content of the cycling cells is just below 3, $(0.35 \cdot 1+0.65 \cdot x=2.1, x=2.7)$. For the few days prior to day 43 , the cell cycle altering compound(s) had slowed down or stopped cells in the cycle following the first round of replication, but not for long enough to lead lead to a build up of a peak corresponding to three chromosomal equivalents as is observed in batch cultures with conditioned medium. ${ }^{11,12}$

Around day 43 the cell cycle altering compound has been diluted sufficiently to alleviate the blockage, and the cells complete the second round of DNA replication, the mother cells begin to break up to release the autospores, the cell concentration increases, and it reaches a maximum at day 49 . The autospores then commit to the first round of replication. Their second round of replication is then blocked or partially blocked because of the increase in concentration of the cell cycle altering compound that must have occurred since its minimum concentration around day 44 , and the oscillatory cycle 


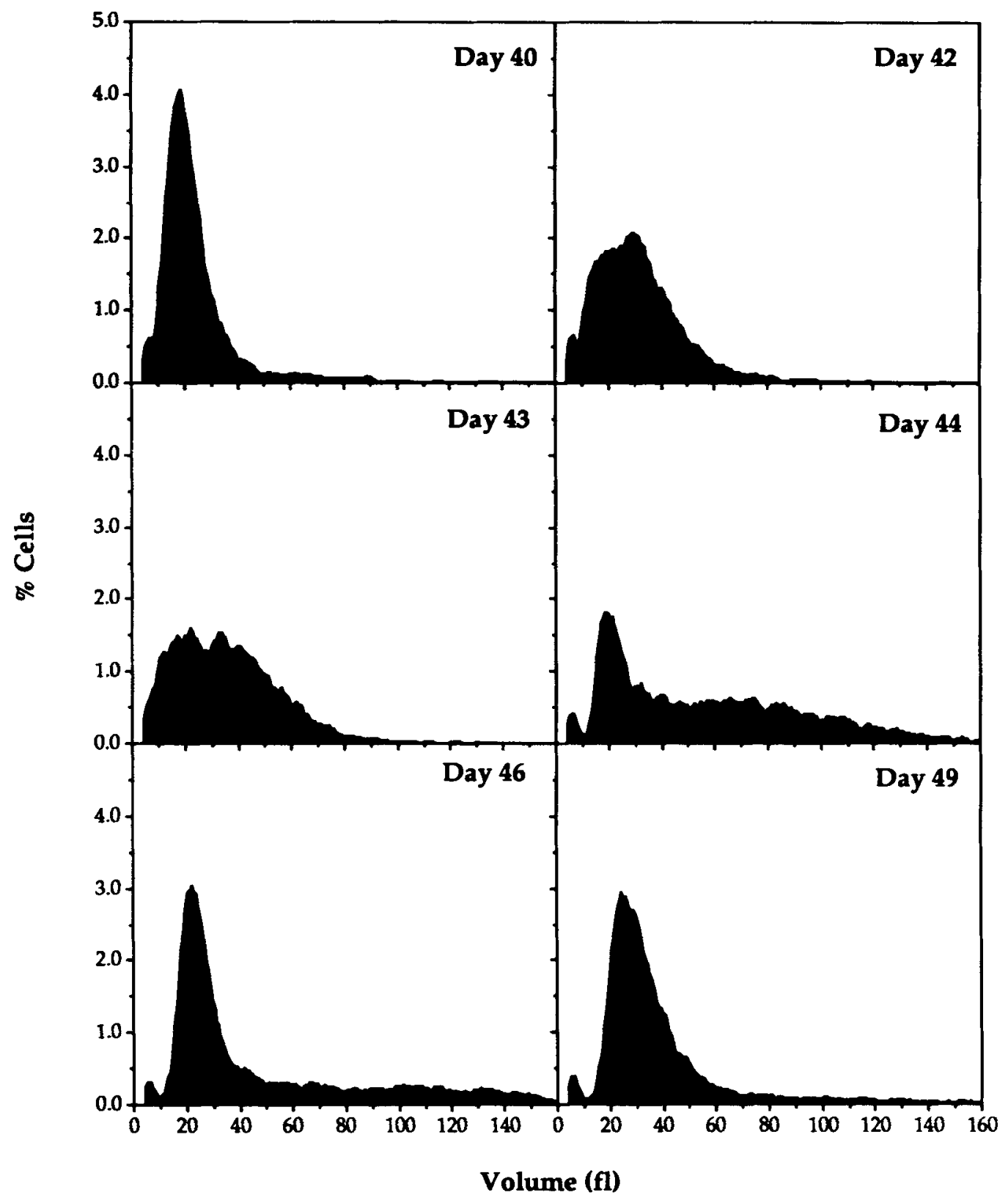

Figure 6. The time sequence of cell size distribution during the second period of oscillation (days 40-50); see Figure 1 and text for details.

is complete. Note that the closeness of cell cycle time to the residence time $(1 / D=10$ days) supports such an inhibition-dilution mechanism.

In this model of the observed oscillatory cycle, the cell-cycle-altering compound is probably released during the cell breakup. The chemical identification of this compound is not completed yet, but our current data shows that its molecular weight is approximately 500 700 daltons. $^{13}$

This project was funded through an Ann Arbor-based NASA Center for Commercial Development of Space (CCDS) and by Grant Award NAGW-2608 from NASA/Headquarters for Photobioreactor Engineering.

\section{APPENDIX}

\section{Calculations of Biomass Productivities Based on the Available Carbon and Nitrogen Sources}

The stoichiometry equation for algal cells with nitrate as the nitrogen source was obtained by Pirt and his coworkers, ${ }^{16}$ as the following equation:

$0.71 \mathrm{CO}_{2}+0.59 \mathrm{H}_{2} \mathrm{O}+0.101 \mathrm{NO}_{3}^{-}+$minerals $+h v \longrightarrow$

$0.71 \mathrm{C}$-mole biomass $+\mathrm{O}_{2}$

One C-mole of ash free biomass is taken to be $\mathrm{C}_{1.0} \mathrm{H}_{1.8} \mathrm{O}_{0.432} \mathrm{~N}_{0.143}$, which has the formula weight of $22.7 \mathrm{~g} / \mathrm{mol}$. The composition of dry cells can be deduced from the following table: 


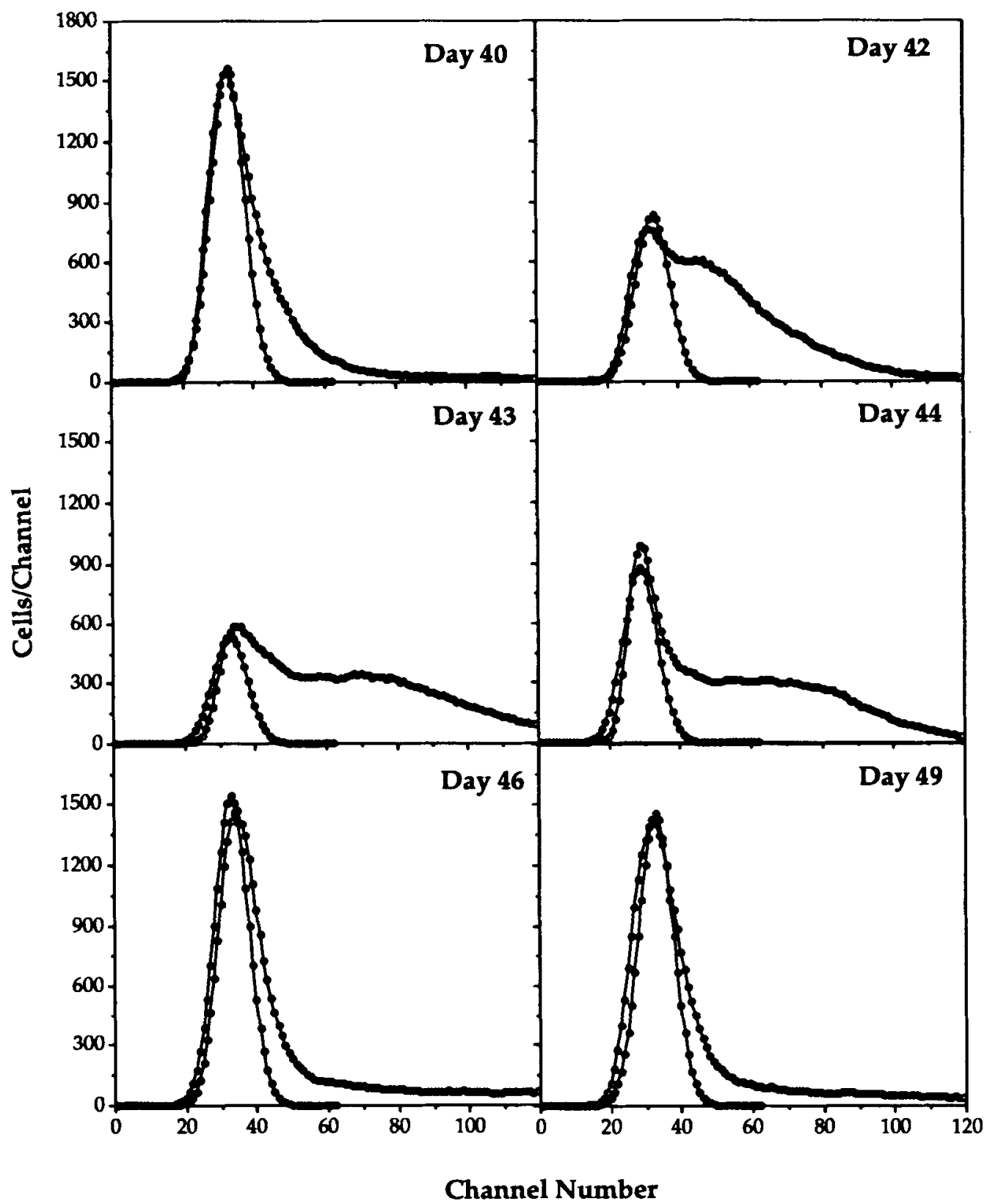

Figure 7. Comparison between the DNA histograms and the Gaussian curve representing the G0/G1 phase cells that has been fit to them to estimate the fraction of noncycling cells. The DNA histograms shown are from the second period of oscillation.

\begin{tabular}{lc}
\hline Compound & $\begin{array}{c}\text { Dry cell } \\
\text { composition }(\%)\end{array}$ \\
\hline Carbon & 52.8 \\
Oxygen & 30.5 \\
Nitrogen & 8.8 \\
Hydrogen & 7.9 \\
\hline
\end{tabular}

The estimated carbon content of dry cells using this method is in agreement with calculated carbon content of diatoms using correlations obtained by Mullin et al. ${ }^{14}$ and Strathmann, ${ }^{24}$ in which the carbon content of the cells was related to the cell or plasma volume. The comparison between carbon and nitrogen uptake in our culture vs. the available amount will show if the culture is nutrient limited at low dilution rate $(0.1 /$ day $)$.
The sole carbon source in the culture is carbon dioxide. If one assumes that carbon dioxide is used solely for the production of biomass (conversion to carbohydrates is negligible), it is possible to calculate consumed carbon dioxide per day at different dilution rates. At low dilution rate $(0.1 /$ day $)$, the volumetric productivity was calculated to be $2.25 \times 10^{6} \mathrm{cells} / \mathrm{mL} / \mathrm{day}$, and the total productivity was $5.625 \times 10^{8}$ cells/day. If one assumes an average cell volume of $40 \mathrm{fl}$ and dry-to-fresh weight ratio of 0.25 , and fresh cell density of $1 \mathrm{~g} / \mathrm{mL}$, we can estimate the dry weight of each cell to be:

$\frac{1 \mathrm{~mL}}{40 \cdot 10^{-12} \mathrm{~mL} / \text { cell }} \times(1 \mathrm{~g}$ fresh cell $/ \mathrm{mL})$

$$
\times \frac{0.25 \mathrm{~g} \text { dry cell }}{1 \mathrm{~g} \text { fresh cell }}=10^{-11} \mathrm{~g}(\mathrm{dry}) / \mathrm{cell}
$$




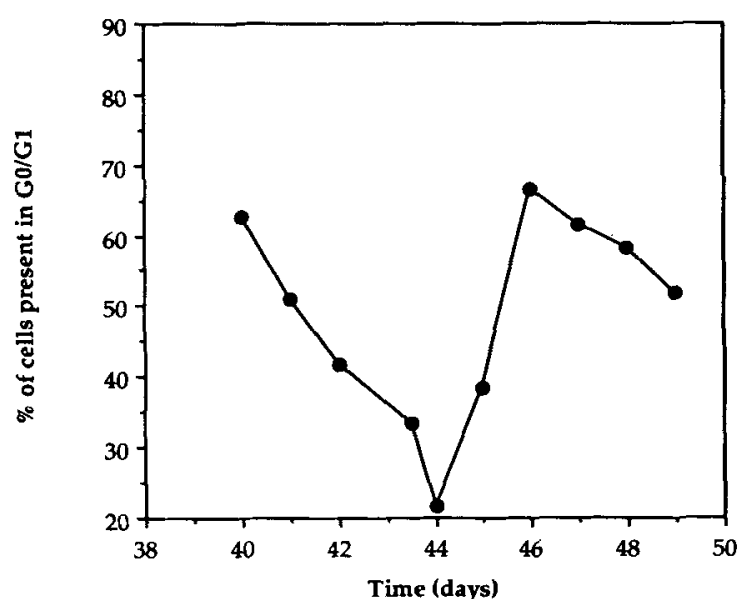

(A)

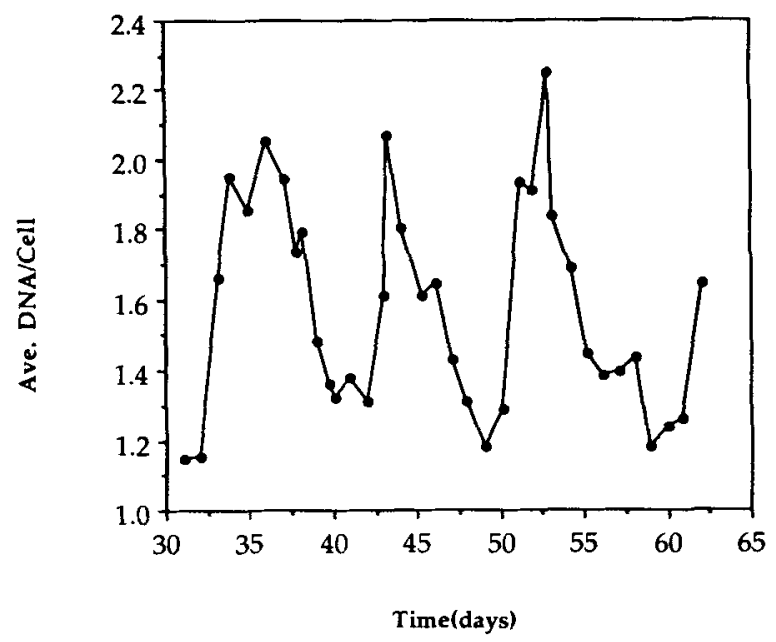

(B)

Figure 8. (A) Calculated percentage of the cells present in G0/G1 phase during the second oscillation as shown in Figure 7. (B) The average DNA content of the cells during the entire oscillation period.

The total dry biomass productivity of the reactor at low dilution rate will then be:

$$
5.625 \cdot 10^{8} \text { cells } / \mathrm{mL} \cdot 10^{-11} \mathrm{~g} / \mathrm{cell}=5.625 \cdot 10^{-3} \mathrm{~g} / \text { day }
$$

The yield coefficient for carbon dioxide and nitrate as substrate can be calculated as:

$$
Y_{x / C}=\frac{1 \mathrm{~g} \mathrm{cell}}{0.528 \mathrm{~g} \mathrm{C}}
$$

or for carbon dioxide:

$$
Y_{x / \mathrm{CO}_{2}}=\frac{1 \mathrm{~g} \text { cell }}{0.528 \mathrm{~g} \mathrm{C} \frac{44 \mathrm{~g} \mathrm{CO}_{2}}{12 \mathrm{~g} \mathrm{C}}}=\frac{1 \mathrm{~g} \text { cell }}{1.936 \mathrm{~g} \mathrm{CO}_{2}}
$$

and for nitrogen:

$$
Y_{x / \mathrm{N}}=\frac{1 \mathrm{~g} \text { cell }}{0.088 \mathrm{~g} \mathrm{~N}}
$$

or for nitrate:

$$
Y_{z / \mathrm{KNO}_{3}}=\frac{1 \mathrm{~g} \text { cell }}{0.088 \mathrm{~g} \mathrm{~N} \frac{101 \mathrm{~g} \mathrm{KNO}}{14 \mathrm{~g} \mathrm{~N}}}=\frac{1 \mathrm{~g} \text { cell }}{7.21 \mathrm{~g} \mathrm{KNO}_{3}}
$$

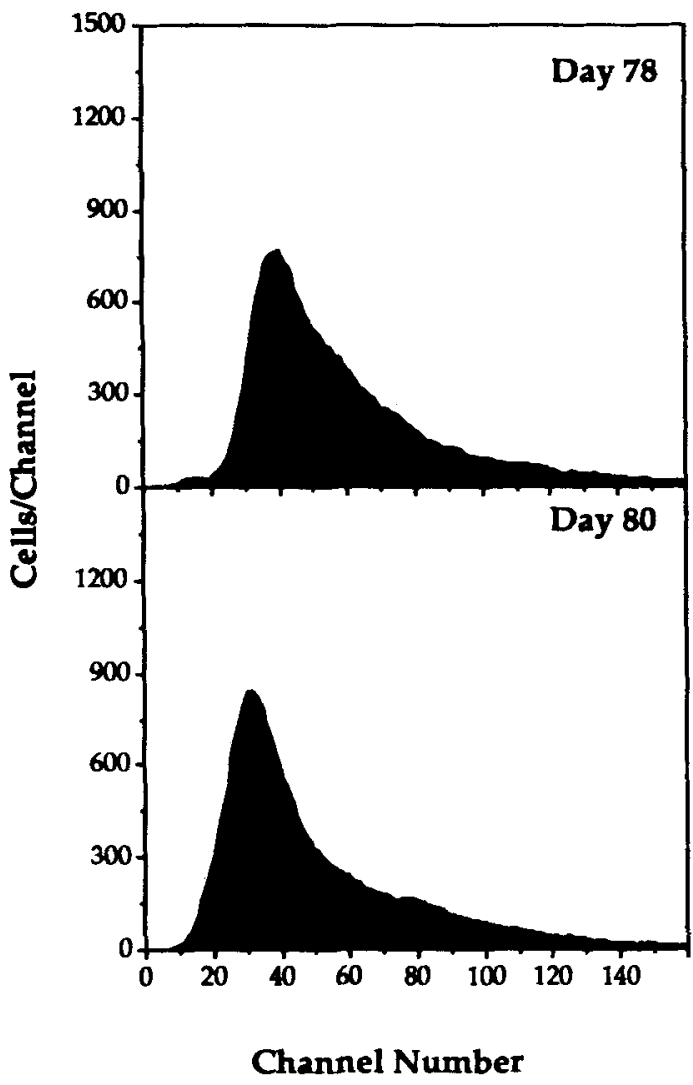

Figure 9. DNA histograms at a high dilution rate (0.3/day); see Figure 1 and text for details.

A total mass balance on carbon and nitrogen will provide the amount of unconsumed carbon and nitrogen source and consequently will demonstrate whether the culture is nutrient limited:

$$
\left(\mathrm{CO}_{2}\right)_{\text {in }}=\left(\mathrm{CO}_{2}\right)_{\text {out }}+\left(\mathrm{CO}_{2}\right)_{\mathrm{C}}
$$

Where $\mathrm{CO}_{\text {in }}$ is the supply of carbon dioxide and $\left(\mathrm{CO}_{2}\right)_{C}$ is the consumed carbon dioxide. Both are readily calculated:

$\left(\mathrm{CO}_{2}\right)_{\text {in }}$

$=100 \mathrm{~mL} / \mathrm{min} \cdot 0.05 \mathrm{~mL} \mathrm{CO} /$ tot. $\mathrm{mL} \cdot \frac{44 \mathrm{~g} \mathrm{CO}_{2}}{22400 \mathrm{~mL}} \cdot 1400 \mathrm{~min} / \mathrm{day}$

$=14.14 \mathrm{~g} / \mathrm{day}$

and

$$
\begin{aligned}
\left(\mathrm{CO}_{2}\right)_{C} & =\text { (biomass productivity }) \times Y_{x / \mathrm{CO}_{2}} \\
& =5.526 \cdot 10^{-3} \cdot 1.936 \\
& =0.01 \mathrm{~g} / \text { day }
\end{aligned}
$$

The carbon assimilated thus is only a small fraction of the carbon supplied.

The unused carbon dioxide in the culture $\left(\mathrm{CO}_{2}\right)_{\text {out }}$ is about $14.13 \mathrm{~g} /$ day, and the excess carbon can support a culture with at least three orders of magnitude higher concentration.

Similar calculations can be carried out for the nitrogen source, where:

$$
\begin{aligned}
\left(\mathrm{KNO}_{3}\right)_{\text {in }} & =1 \mathrm{~g} / \mathrm{L} \times 0.25 \mathrm{~L} / \text { day } \\
& =0.25 \mathrm{~g} / \text { day }
\end{aligned}
$$

and

$$
\begin{aligned}
\left(\mathrm{KNO}_{3}\right)_{C} & =\text { (biomass productivity) } \cdot Y_{x / \mathrm{KNO}_{3}} \\
& =5.526 \cdot 10^{-3} \times 7.21 \\
& =0.04 \mathrm{~g} / \text { day }
\end{aligned}
$$


The unused nitrate in the culture $\left(\mathrm{KNO}_{3}\right)$ is about $0.21 \mathrm{~g} /$ day, and the excess nitrate can support a culture with at least one order of magnitude higher concentration.

\section{References}

1. Bold, H.C., Wynne, M. J. 1978. Introduction to the algae, structure and reproduction. Prentice Hall, Englewood Cliffs, NJ.

2. Borowitzka, L. J., Borowitzka, M. A. 1989. Industrial production: methods and economics. p. 294-316 In: R. C. Cresswell, T.A.V. Rees, and H. Shah (eds.), Algal and Cynobacterial Biotechnology. Longman Scientific \& Technical, Harlow, England.

3. Bruce, L. J., Axford, D. B., Ciszek, B., Daugulis, A. J. 1991. Extractive fermentation by Zymomonas mobilis and the control of oscillatory behavior. Biotechnol. Lett. 13: 291-296.

4. Chapman, D. J., Gellenbeck, K.W. 1989. A historical perspective of algal biotechnology. p. 1-27 In: R. C. Cresswell, T. A.V. Rees, and H. Shah (eds.), Algal and cynobacterial biotechnology. Longman Scientific \& Technical, Harlow, England.

5. Chen, C.-I., McDonald, K.A. 1990. Oscillatory behavior of Saccharomyces cerevisiae in continuous culture: I. effects of $\mathrm{pH}$ and nitrogen levels. Biotechnol. Bioeng. 36: 19-27.

6. Chen, C.-I., McDonald, K. A. 1990. Oscillatory behavior of Saccharomyces cerevisiae in continuous culture: II. analysis of cell synchronization and metabolism. Biotechnol. Bioeng. 36: $28-38$.

7. Chisholm, S.W. 1981. Temporal patterns of cell division in unicellular algae. p. 150-181 In: T. Platt (ed.), Physiological bases for phytoplankton ecology. Ottawa Dept. of Fisheries and Oceans, Ottawa.

8. Davis, E. A., Dedrick, J., Smith, J. H. C., Spoehr, H. A. 1953 Laboratory experiments on chlorella culture at the Carnegie Institution of Washington, p. 105-153. In: J. S. Burlew (ed.), Algal culture from laboratory to pilot plant. Carnegie Institution of Washington publication, Washington, DC.

9. Faulkner, D. J. 1977. Interesting aspects of marine natural products chemistry. Tetrahedron 33: 1421-1443.

10. Faulkner, D. J. 1978. Antibiotics from marine organisms. Top. Antibiot. Chem. 2: 9-58.

11. Javanmardian, M., Palsson, B. $\varnothing$. The effect of conditioned medium on the cell cycle of Chlorella vulgaris. Submitted.

12. Javanmardian, M., Palsson, B. Ø. High-density photoautotrophic algal cultures: Design, construction, and operation of a novel photobioreactor system. Biotechnol. Bioeng. To appear.

13. Javanmardian, M., Palsson, B. $\emptyset$. The effect of different fractions of conditioned medium on the growth and cell cycle of Chlorella vulgaris. Submitted.
14. Mullin, M. M., Sloan, P. R., Eppley, R.W. 1966. Relationship between carbon content, cell volume, and area in phytoplankton. Limnol. Oceanogr. 11: 307-311.

15. Myers, J., Graham, J. 1959. Yield as a function of cell concentration under continuous sunlight irradience. Plant Physiol. 34: 345-352.

16. Pirt, S. J., Lee, Y.-K., Pichmond, A., Watts-Pirt, M, 1980. The photosynthetic efficiency of Chlorella biomass growth with reference to solar energy utilization. J. Chem. Technol. Biotechnol. 30: 25-34.

17. Pratt, R. 1941. Studies on Chlorella vulgaris V. Some properties of the growth-inhibitor formed by Chlorella cells. Am. J. Bot. 29: 142-148.

18. Pratt, R. 1942. Studies on Chlorella vulgaris. VI Retardation of photosynthesis by a growth-inhibiting substance from Chlorella vulgaris. Am. J. Bot. 30: 32-33.

19. Pratt, R. 1944. Studies on Chlorella vulgaris. IX. Influence on growth of Chlorella of continuous removal of chlorellin from the culture solution. Am. J. Bot. 31: 418-421.

20. Pratt, R., Daniels, T. C., Eiler, J. B., Stain, H. H. 1944. Chlorellin, an antibacterial substance from Chlorella. Science 99: 351-352.

21. Pratt, R., Fong, J. 1940. Studies on Chlorella vulgaris II. Further evidence that Chlorella cells form a growth-inhibiting substance. Am. J. Bot. 27: 431-436.

22. Pratt, R., Oneto, J. F., Pratt, J. 1945. Studies on Chlorella vulgaris. $\mathrm{X}$. Influence of the age of the culture on the accumulation of the chlorellin. Am. J. Bot. 32: 405-408.

23. Shinho, K. 1986. Antitumor glycoproteins from Chlorella and other species. Jpn. Kokai Tokkyo Koho, JP 61 69.728(86 69.728):105:30034t, 1986.

24. Stathmann, R. R. 1967. Estimation of organic carbon content of phytoplankton from cell volume or plasma volume. Limnol. Oceangr. 12: 411-418.

25. Strassle, C., Sonnleitner, B., Fiechter, A. 1989. A predictive model for the spontaneous synchronization of Saccharomyces cerevisiae grown in continuous culture. J. Biotechnol. 9: 191208.

26. Tamiya, H. 1964. Growth and cell division of Chlorella. p. 247305. In: E. Zeuthen (ed.), Synchrony in cell division and growth. Interscience Publishers, New York.

27. Vonmeyenberg, K. 1973. Stable synchrony oscillations in continuous cultures of Saccharomyces cerevisiae under glucose limitations. p. 411-417. In: B. Chance, E. K. Pye, A. K. Ghosh, and B. Hess (eds.), Biological and biochemical oscillators, Academic Press, New York. 